\title{
Quality Characteristics of Noodle Including Ground Yellow Poppy Seed
}

\author{
Seda YALCIN *1, Besim MADEN ${ }^{1}$ \\ ${ }^{1}$ Afyon Vocational School, Food Technology Programme, Afyon Kocatepe University, Afyon, Turkey
}

Received: 03 May 2017 - Revised: 11 July 2017 - Accepted: 03 September 2017

\begin{abstract}
The objective of this study is the production of noodle including ground yellow poppy seed which has phenolic compounds. Phenolic compounds have antioxidant activity. According to the researches, these compounds reduce risk of many diseases like cancer. In this study, ground yellow poppy seed (purchased from Afyon) was added to the noodle formulation at the ratios of 5\% and $10 \%$. Flour used in the production was obtained by milling of two wheat variety (Kunduru and Altıntas). The control sample was noodle sample including no ground yellow poppy seed. After production, quality characteristics, total phenolic content and color values of noodle samples were analyzed. Quality characteristics of noodle samples made from Kunduru wheat flour were higher than that of noodle samples made from Altıntas wheat flour. Ground yellow poppy seed addition caused dark color at the noodle samples. Control samples had higher quality characteristics compared to noodle samples including ground yellow poppy seed. Higher phenolic content was observed for noodle samples including ground yellow poppy seed.
\end{abstract}

Keywords: Poppy seed, Noodle, Phenolic

\section{INTRODUCTION}

Poppy (papaver somniferum) is cultivated as an annual crop in some countries (China, India, Turkey) [1]. Ozcan and Atalay [1] determined palmitic acid, stearic acid, oleic acid, linoleic acid and linolenic acid in poppy seed oils. Poppy seed oils had $\alpha$-tocopherol, $\beta$ tocopherol and $\delta$-tocopherol in the range of $26.8-37.2 \mathrm{ppm}, 309.5-567.3 \mathrm{ppm}$, and 6.1-18.6 ppm, respectively. Poppy seeds had high amount of $\mathrm{P}, \mathrm{K}, \mathrm{Ca}, \mathrm{Mg}, \mathrm{Na}$, and $\mathrm{Fe}$ [1]. Bozan and Temelli [2] demonstrated that total phenolic content of poppy seed was $930 \mathrm{mg} / 100 \mathrm{~g}$. Emir et al. [3] investigated sensory properties, aromatic profiles and consumer preferences of cold pressed poppy seed oils and reported that roasting before cold pressing improved sweet aromatic values and roasted samples were more liked by consumers. The yellow (produced in Afyon) roasted sample was the most preferred sample (53.55\%) by consumers in all samples (white, yellow, blue).

Noodles are classfied into different types on the basis of raw material, processing methods, composition and shape of strands [4]. There are researches for increasing of total phenolic content in noodle, pasta and spaghetti, because phenolics have antioxidant activity.

${ }^{*}$ Corresponding Author E-mail: syalcin@aku.edu.tr 
Khan et al. 2013[5] reported that addition of red sorghum flour and white sorghum flour to durum wheat pasta formulation increased total phenolic content of pasta due to sorghum contains polyphenolic antioxidants. Total phenolic content of wheat pasta was increased with increasing of addition level of red sorghum flour and white sorghum flour. Wheat pasta had $0,77 \mathrm{mg} \mathrm{GAE} / \mathrm{g}$ total phenolic content, while wheat pasta including red sorghum flour had 1,88 $\mathrm{mg} \mathrm{GAE} / \mathrm{g}$ total phenolics content and wheat pasta including white sorghum flour had 1,06 mg GAE/g total phenolic content. Total phenolic content of wheat pasta including red sorghum flour was higher than that of wheat pasta including white sorghum flour because red sorghum flour had higher total phenolic content $(6,65 \mathrm{mg} \mathrm{GAE} / \mathrm{g})$ compared to white sorghum flour $(2,17$ mg GAE/g)

There are some studies about increasing of total phenolic content of noodle, pasta and spaghetti. But there is no study about the effect of utilization of ground yellow poppy seed in noodle formulation to increase total phenolic content. The objective of this study was to evaluate the effect of ground yellow poppy seed addition to wheat noodle on quality characteristics, color values and total phenolic content of noodle.

\section{MATERIAL and METHODS}

\subsection{Materials}

Flours of two Turkish wheat cultivars (grown in Afyon), Kunduru-1149 and Altıntas-95, were supplied from Tinaztepe factory (Afyon, Turkey). Ground yellow poppy seed was purchased from local producer (Afyon).

\subsection{Grain characteristics}

Grain vitreousness was assessed by analysis of kernel cross sections using Grobecker kernel cutter and expressed as percentage of vitreous grains. Hectoliter weight of wheat samples was determined according to the AACC approved method [6]. Thousand kernel weight of wheat samples was determined according to the method of TS 1136. The experiments were performed in three replications.

\subsection{Flour characteristics}

Moisture, ash, protein (Nx 5.70), wet gluten and dry gluten contents of wheat flours were determined according to the AACC approved methods [6]. Zeleny sedimentation and modified sedimentation values of wheat flours were measured according to the method of ICC (116/1) [7]. Farinograph characteristics of wheat flours were determined according to ICC method (115/1) [7] using Brabender Farinograph (Brabender OHG, Duisburg, Germany). The experiments were performed in three replications.

\subsection{Poppy seed characteristic}

Oil content of ground yellow poppy seed was determined according to the method of AOAC [8] and color values $\left(\mathrm{L}^{*}, \mathrm{a}^{*}, \mathrm{~b}^{*}\right)$ of sample were performed by using X-rite spectrophotometer (USA).

\subsection{Noodle preparation and analysis}

The wheat flour and ground yellow poppy seed $(5 \%, 10 \%)$ were mixed with $60 \%$ water in a mixer (Essenso Professeur 216912, China) for $10 \mathrm{~min}$ at a speed 1 . The dough was sheeted by a sheeting roller. The dough sheet was cut into strips by pasta machine (Essenso Professeur 981121, China). Dough strips were dried at room temperature $\left(25^{\circ} \mathrm{C}\right)$. The final dried noodle samples contained a maximum of $9 \%$ moisture. The noodles were packed into plastic bags and stored until analyses. The samples were evaluated in terms of cooking, color properties and total phenolic content. 


\subsubsection{Cooking analysis}

Noodle (25 g), cut into pieces of $2.5 \mathrm{~cm}$, was cooked in boiling water $(100 \mathrm{ml})$. The optimum cooking time of noodle was determined as the time required for disappearance of white core when compressed between two glass slides. Cooking loss is the amount of solid substance lost to cooking water. For determining of cooking loss, the cooking water was collected in a tarred beaker and evaporated to dryness in an oven at $98^{\circ} \mathrm{C}$. The residue was weighted and reported as percentage of the starting material. Water absorption (\%) and swelling volume $(\%)$ of the noodle samples were calculated as follows;

$$
\text { Waterabsorption }(\%)=\frac{\text { weightof cookednoodle }- \text { weightof uncookechoodle }}{\text { weightof uncookechoodle }} \times 100
$$

$$
\text { Swellingvolume }(\%)=\frac{\text { volumeof cookednoodle volumeof uncookehoodle }}{\text { volumeof uncookedhoodle }} \times 100
$$

The cooking time, cooking loss, water absorption and swelling volume analysis were carried out in duplicate.

\subsubsection{Color analysis}

The color measurement $\left(\mathrm{L}^{*}, \mathrm{a}^{*}, \mathrm{~b}^{*}\right)$ of noodle samples was carried out in duplicate using the $\mathrm{L}^{*} \mathrm{a}^{*} \mathrm{~b}^{*}$ color system, where $\mathrm{L}^{*}$ is lightness, $\mathrm{a}^{*}$ is redness, and $\mathrm{b}^{*}$ is yellowness. The instrument used was a X-rite (USA).

\subsubsection{Total phenolic content}

Extracion of samples was carried out according to the method reported by Awika et al. [9]. Samples $(1 \mathrm{~g})$ were mixed with $10 \mathrm{~mL}$ of $1 \% \mathrm{HCL}$ in methanol for $1 \mathrm{~h}$ and centrifuged at $3000 \mathrm{rpm}$ for $20 \mathrm{~min}$ (DAIHAN Scientific Co., Ltd., WiseSpin ${ }^{\circledR}$ CF-10 Microcentrifuge, Korea). The supernatant was used for determination of total phenolic content.

Total phenolic content of noodles was determined by the Folin-Ciocalteu method of Li et al. [10]. Sample extract $(0.2 \mathrm{~mL})$ was mixed with $0.8 \mathrm{~mL}$ diluted Folin-Ciocalteu reagent $(1 / 10)$ and waited for $3 \mathrm{~min}$. Then $2 \mathrm{~mL}$ of sodium carbonate solution $(15 \%$, w/v) was added to mixture. After addition of $2 \mathrm{~mL}$ distilled water, the mixture was vortexed and kept at room temperature for $1 \mathrm{~h}$ in the dark. The absorbance was measured at $760 \mathrm{~nm}$ using UV-Vis spectrophotometer (Optizen pop, Korea). Gallic acid $(0-0.5 \mathrm{mg} / \mathrm{mL})$ prepared in methanol, was used as standard. The results were expressed as mg gallic acid (GAE) /g sample (dry basis). The analysis was carried out in duplicate.

\subsection{Statistical analysis}

Data related to cooking properties color, properties and total phenolic content of the noodle samples were statistically evaluated by one-way analysis of variance procedure. Duncan test was applied to compare mean values.

\section{RESULTS and DISCUSSIONS}

\subsection{Grain characteristics}

Physical properties of wheat samples (Kunduru-1149 and Altıntas-95) are given in Table 1. Kunduru-1149 had 59.3\% vitreous kernels, while Altıntas-95 had 82.7\% vitreous kernels. According to Dexter et al. [11], semolina yield was reduced with decreasing of vitreous kernels. Vitreous durum wheat is harder than starchy durum wheat and gives higher yield of semolina and lower yield of flour. The thousand kernel weight is associated with average kernel size. 
Larger kernel causes higher milling yield [12]. The thousand kernel weights of Kunduru-1149 and Altıntas-95 were $41.7 \mathrm{~g}$ and $37.7 \mathrm{~g}$, respectively. Kunduru- 1149 had higher thousand kernel weight and higher milling/semolina yield than Altıntas-95. Hectoliter weight of Kunduru-1149 was higher than that of Altıntas-95. Hectoliter weight exhibits a linear relation with kernel weight and therefore milling/semolina yield [11].

Table 1. Physical and Chemical Properties of Wheat Grain

\begin{tabular}{lcc}
\hline Physical and Chemical Properties of & Kunduru -1149 & Altnntas - 95 \\
Wheat Grain & & 77.1 \\
\hline Hectoliter weight $(\mathrm{kg} / \mathrm{hl})$ & 78.3 & 37.7 \\
Thousand kernel weight $(\mathrm{g})$ & 41.7 & 82.7 \\
Vitreousness (\%) & 59.3 & 1.6 \\
Ash content (\%) & 1.7 & 14.5 \\
Protein content (\%) & 12.2 & \\
\hline
\end{tabular}

\subsection{Flour characteristics}

The moisture contents of wheat flours (Kunduru-1149 and Altıntas-95) were $12.8 \%$ and $14.2 \%$, while their ash contents were $1.7 \%$ and $1.6 \%$, respectively. The protein contents of wheat flours (Kunduru-1149 and Altıntas-95) were 12.2\% and 14.5\% (d.b.), respectively. Physicochemical characteristics of durum wheat samples (Kunduru-1149 and Altıntas-95) are given in Table 1.

Altıntas-95 had higher protein content and also higher wet gluten content (27.3\%) than those of Kunduru-1149 (22.7\%). Altıntas-95 wheat flour had higher zeleny sedimentation volume than Kunduru-1149 wheat flour due to having higher protein content. The protein quality according to zeleny test was higher for the Altıntas-95 wheat flour $(29.7 \mathrm{ml})$ compared to that for the Kunduru-1149 wheat flour $(21.3 \mathrm{ml})$.

Farinograph results of wheat flours are given in Table 2. water absorption of kunduru1149 wheat flour was $61.0 \%$, while that of Altıntas-95 wheat flour was $61.5 \%$. Kunduru- 1149 wheat flour had lower dough development time and maximum consistency than Altıntas-95 wheat flour. Tolerance index of Kunduru-1149 wheat flour was higher than that of Altıntas-95 wheat flour.

Table 2. Gluten and Farinograph Properties of Wheat Flour

\begin{tabular}{lcc}
\hline Farinograph and Gluten Properties of Wheat Flour & Kunduru -1149 & Altıntas - 95 \\
\hline Development time (min) & 9.4 & 14.3 \\
Max. Consistency (B.U.) & 400 & 445.0 \\
Mixing Tolerance (B.U.) & 28.3 & 6.7 \\
Zeleny Sedimentation (ml) & 21.3 & 29.7 \\
Modified Zeleny Sedimentation (ml) & 24.7 & 32.3 \\
Gluten & 22.7 & 27.3 \\
\hline
\end{tabular}




\subsection{Poppy seed characteristics}

Oil content of ground yellow poppy seed was found as $49.85 \%$. L*, a*, b* color values of sample were $60.08,-2.78$ and 12.52 , respectively.

\subsection{Analysis of noodle}

\subsubsection{Cooking time}

Cooking time values of the noodles are found as $20 \mathrm{~min}$.

\subsubsection{Cooking loss}

Cooking loss values of noodles are given in Table 3. Addition level of ground yellow poppy seed to noodle caused significant changes in cooking loss values of noodles (Table 3 ). Noodle samples including 10\% ground yellow poppy seed had the lowest cooking loss in noodle samples tested. Cooking loss values of noodles decreased significantly, as the level of ground yellow poppy seed in noodle decreased. Noodle samples prepared from Kunduru-1149 wheat sample were found to have significantly lower cooking loss values as compared to their respective samples prepared from Altıntas-95 wheat sample, indicating better quality. The higher cooking loss of noodles including ground yellow poppy seed might be due to decreasing of gluten content in noodle. Because ground yellow poppy seed have not gluten protein. But the results of noodle samples including ground yellow poppy seed were also acceptable due to lower than $8 \%$ [5]. The similar effect was observed for wheat pasta incorreperating with sorghum flour [5].

Table 3. Properties of noodles

\begin{tabular}{cccccccc}
\hline Samples & $\begin{array}{c}\text { Cooking } \\
\text { loss } \\
(\%)\end{array}$ & $\begin{array}{c}\text { Water } \\
\text { absorption } \\
(\%)\end{array}$ & $\begin{array}{c}\text { Swelling } \\
\text { volume } \\
(\%)\end{array}$ & L $^{*}$ & $\mathrm{a}^{*}$ & $\mathrm{~b}^{*}$ & $\begin{array}{c}\text { Total phenolic } \\
\text { content } \\
(\mathrm{mg} \mathrm{GAE} / \mathrm{g})\end{array}$ \\
\hline K1 & $1.64^{\mathrm{e}}$ & $177.5^{\mathrm{a}}$ & $226.5^{\mathrm{a}}$ & $89.55^{\mathrm{a}}$ & $5.09^{\mathrm{e}}$ & $15.92^{\mathrm{d}}$ & $0.50^{\mathrm{f}}$ \\
K2 & $2.84^{\mathrm{c}}$ & $146.0^{\mathrm{c}}$ & $194.5^{\mathrm{b}}$ & $83.83^{\mathrm{c}}$ & $5.67^{\mathrm{d}}$ & $16.92^{\mathrm{c}}$ & $0.69^{\mathrm{d}}$ \\
K3 & $3.58^{\mathrm{b}}$ & $107.0^{\mathrm{d}}$ & $131.5^{\mathrm{c}}$ & $82.66^{\mathrm{d}}$ & $7.14^{\mathrm{a}}$ & $19.88^{\mathrm{a}}$ & $0.89^{\mathrm{f}}$ \\
$\mathrm{A} 1$ & $2.12^{\mathrm{d}}$ & $172.5^{\mathrm{b}}$ & $222.0^{\mathrm{ab}}$ & $89.49^{\mathrm{a}}$ & $5.01^{\mathrm{e}}$ & $16.18^{\mathrm{d}}$ & $0.55^{\mathrm{e}}$ \\
A2 & $3.62^{\mathrm{b}}$ & $96.0^{\mathrm{e}}$ & $133.0^{\mathrm{c}}$ & $85.25^{\mathrm{b}}$ & $6.00^{\mathrm{c}}$ & $18.16^{\mathrm{b}}$ & $0.79^{\mathrm{c}}$ \\
$\mathrm{A} 3$ & $4.65^{\mathrm{a}}$ & $81.5^{\mathrm{f}}$ & $92.0^{\mathrm{d}}$ & $84.04^{\mathrm{c}}$ & $6.91^{\mathrm{b}}$ & $20.21^{\mathrm{a}}$ & $0.93^{\mathrm{a}}$ \\
\hline
\end{tabular}

Note: K1: control noodle (Prepared from Kunduru -1149 flour); K2: noodle including $5 \%$ ground yellow poppy seed (Prepared from Kunduru -1149 flour ); K3: noodle including $10 \%$ ground yellow poppy seed (Prepared from Kunduru -1149 flour); A1: control noodle (Prepared from Altıntas - 95 flour); A2: noodle including $5 \%$ ground yellow poppy seed (Prepared from Altıntas - 95 flour); A3: noodle including $10 \%$ ground yellow poppy seed ( Prepared from Altıntas - 95 flour).

\subsubsection{Water absorption}

Water absorption values of noodles are given in Table 3. Addition level of ground yellow poppy seed to noodle caused significant changes in water absorption values of noodles (Table 3 ). Noodle samples including $10 \%$ ground yellow poppy seed had the lowest water absorption in noodle samples tested. Water absorption values of noodles decreased, as the level of ground yellow poppy seed in noodle increased. The lower starch content is a major reason for the lower water absorption of noodles including ground yellow poppy seed. Noodle samples prepared from Kunduru-1149 wheat sample resulted in significantly higher water absorption values when compared with those of noodle samples prepared from Altıntaş-95 wheat sample indicating better quality.

\subsubsection{Swelling volume}

Swelling volume values of noodles are given in Table 3. Addition level of ground yellow poppy seed to noodle formulation caused significant changes in swelling volume values of 
noodles (Table 3). Noodle samples including 10\% ground yellow poppy seed had the lowest swelling volume in noodle samples tested. Swelling volume of noodle increased, as the level of ground yellow poppy seed in noodle decreased. Noodle samples prepared from Kunduru-1149 wheat sample had significantly higher swelling volume values than that of noodle samples prepared from Altıntas-95 wheat sample indicating better quality.

\subsubsection{Color properties}

The colors of noodles are given in Table 3. The color of noodle is an important quality factor which influences consumer preference [13]. The level of ground yellow poppy seed in noodle significantly affected the $\mathrm{L}^{*}, \mathrm{a}^{*}$ and $\mathrm{b}^{*}$ color values of noodles. Noodles became darker with the increased level of ground yellow poppy seed in noodles. Noodle samples prepared from Kunduru-1149 wheat sample had $\mathrm{L}^{*}, \mathrm{a}^{*}$ and $\mathrm{b}^{*}$ color values comparable to their respective samples prepared from Altıntas-95 wheat sample.

\subsubsection{Total phenolic contents}

Total phenolic contents of noodles are given in Table 3. Ground yellow poppy seed significantly affected total phenolic content of noodles. Total phenolic content of noodles increased with increasing of ground yellow poppy seed in noodles. Noodles including $10 \%$ ground yellow poppy seed had significantly highest antioxidant activity due to having highest total phenolic content. Noodle samples prepared from Altıntas-95 wheat flour had significantly higher total phenolic content than that of noodle samples prepared from Kunduru-1149 wheat flour. The increase in total phenolic content was observed for wheat pasta after addition of sorghum flour [5].

\section{CONCLUSIONS}

In this study, ground yellow poppy seed was added to wheat noodle formulation for increasing of total phenolic content of noodle. Then the effect of utilization of ground yellow poppy seed in noodle on quality characteristics of noodle was studied. Quality characteristics of noodles including no ground yellow poppy seed were found better than those of noodles including ground yellow poppy seed. Ground yellow poppy seed enhanced the total phenolic content of noodle. Noodle samples including 10\% ground yellow poppy seed had the highest total phenolic contents. According to literature, phenolics can prevent some diseases So noodles including ground yellow poppy seed were healthier compared to wheat noodle. Ground yellow poppy seed in noodles resulted in decrease in $\mathrm{L}^{*}$ color values and increases in $\mathrm{a}^{*}$ and $\mathrm{b}^{*}$ color values.

\section{Acknowledgement}

We wish to thank Tinaztepe Factory (Afyon, Turkey) for providing wheat flour samples.

\section{Conflict of Interests}

Authors declare that there is no conflict of interests.

\section{REFERENCES}

[1]. Ozcan, M.M., \& Atalay, C. (2006). Determination of seed and oil properties of some poppy (Papaver somniferum L.) varieties. Grasas Aceites, 57(2), 169-174.

[2]. Bozan, B., \& Temelli, F. (2008). Chemical composition and oxidative stability of flax, safflower and poppy seed and seed oils. Bioresource Technol, 99, 6354-6359.

[3]. Emir, D.D., Guneser, O., \& Y1lmaz, E. (2014). Cold pressed poppy seed oils: Sensory properties, aromatic profiles and consumer preferences. Grasas Aceites, 65(3), e029. 
[4]. Fu, B. X. (2008) Asian noodles: Hstory, classification, rax materials, and processing. Food Res. Int., 41,888.

[5]. Khan, I., Yousif, A., Johnson, S. K., \& Gamlath, S. (2013). Effect of sorghum flour addition on resistant starch content, phenolic profile and antioxidant capacity of durum wheat pasta Food Res. Int., 54, 578-586.

[6]. AACC, (2000). Approved methods of the American Association of Cereal Chemists (10th ed.)

[7]. ICC methods (1998) ICC Standards: Standard Methods of the International Association for Cereal Science and Technology, 7th supplement.

[8]. AOAC, (1990). Official Methods of Analysis, 15th edn. Association of official Analytical chemists, Washington, DC.

[9]. Awika, J.M., Rooney, L.W., \& Waniska, R.D. (2004). Properties of 3-Deoxyanthocyanins from Sorghum. J Agric Food Chem, 52, 4388-4394.

[10]. Li, H., Cheng, K., Wong, C., Fan, K., Chen, F., \& Jiang, Y. (2007). Evaluation of antioxidant capacity and total phenolic content of different fractions of selected microalgae. Food Chem, 102, 771-776.

[11]. Dexter, J.E. \& Edwards, N.M. (1998). The implications of frequently encountered grading factors on the processing quality of common wheat. Association of Operative Millers Bulletin, June, 7115-7122.

[12]. Dick, J.W. \& Matsuo, R.R. (1988). Durum wheat and pasta products. In: Wheat Chemistry and Technology, Pomeranz, Y. (ed.). AACC, St. Paul, Minnesota, Vol. pp. 507-547.

[13]. Choy, A-L., Morrison, P.D., Hughes, J.G., Marriott, P.J., \& Small, D.M. (2013). Quality and antioxidant properties of instant noodles enhanced with common buckwheat flour. $J$ Cereal Sci, 57,281-287. 